\title{
As Catadoras de Mangaba no Programa de Aquisição de Alimentos - PAA: um estudo de caso em Sergipe ${ }^{1}$
}

\author{
Dalva Maria da Mota² ${ }^{2}$ Heribert Schmitz ${ }^{3}$, Josué Francisco da Silva Júnior, \\ Noemi Miyasaka Porro ${ }^{5}$ e Tânia Carolina Viana de Oliveira ${ }^{6}$
}

Resumo: $\mathrm{O}$ artigo trata da experiência de um grupo de mulheres extrativistas na comercialização de frutas silvestres, no âmbito do Programa de Aquisição de Alimentos (PAA), no estado de Sergipe. O quadro de análise insere-se no debate sobre pobreza e políticas públicas para grupos específicos no espaço rural. $\mathrm{O}$ foco aqui são as autodenominadas "catadoras de mangaba", que assumiram uma identidade coletiva baseada no uso comum de recursos com baixo impacto ambiental e pertencem ao Movimento das Catadoras de Mangaba (MCM). Embora tenham sido recentemente reconhecidas como sujeitos de direitos específicos, vivenciam a diminuição dos recursos, sobre os quais praticam o extrativismo, e as dificuldades de comercialização resultantes da insegurança relativa ao acesso aos frutos e à sazonalidade. A pesquisa foi realizada entre 2008 e 2011 por meio de observação direta e entrevistas abertas e semiestruturadas. Os principais resultados mostram que o PAA tem influenciado no aumento da renda, do consumo e da autoestima. Houve reordenamento da rotina diária das catadoras de mangaba que, para participar do programa, relegaram atividades tradicionais a segundo plano. As regras do programa foram ressignificadas e adaptadas localmente. Constata-se o aumento da solidariedade entre as catadoras participantes, paralelamente à intensificação da concorrência pelos frutos.

Palavras-chaves: mulheres, extrativistas, comercialização, políticas públicas, Programa de Aquisição de Alimentos.

1. Pesquisa financiada com recursos do Conselho Nacional de Desenvolvimento Científico e Tecnológico (CNPq) do Ministério da Ciência e Tecnologia (MCT), da Empresa Brasileira de Pesquisa Agropecuária (Embrapa) e da Universidade Federal do Pará (UFPA).

2. Doutora em Sociologia, pesquisadora da Embrapa Amazônia Oriental, em Belém (PA), bolsista de produtividade do CNPq. E-mail: dalva.mota@embrapa.br

3. Doutor em Sociologia Rural, professor de Sociologia da UFPA, bolsista de produtividade do CNPq. E-mail: heri@amazonet.com.br

4. Mestre em Fruticultura Tropical, pesquisador da Embrapa Tabuleiros Costeiros, em Aracaju (SE). E-mail: josue.francisco@embrapa.br

5. PhD em Antropologia, professora de Questão Agrária no Núcleo de Ciências Agrárias e Desenvolvimento Rural da UFPA. E-mail: noemi@ufpa.br

6. Bacharel em Ciências Sociais, mestranda em Ciências Sociais pela Universidade Federal de Sergipe (UFS), em São Cristóvão (SE). E-mail: taniacvoliveira@gmail.com 
Abstract: This article is about the experience of a group of women in the commercialization of gathered wild fruits through the governmental Food Purchase Program (PAA) in the Brazilian State of Sergipe. The analytical framework is associated to the debate on poverty and specific public policies for traditional communities in rural areas. The women hold a collective identity as the mangaba gatherers, based on their use of common pool resources with low environmental impact. They mobilize themselves through the MCM - Movimento das Catadoras de Mangaba, Mangaba Gatherer Women's Movement. Although they have recently been recognized as having specific legal rights, they are experiencing the dwindling of the resources they gather, as well as difficulties in commercialization of the fruits due to their seasonality and the unpredictability of access. The research was carried out between 2008 and 2011 and involved direct and participant observations and open-ended interviews. The main results show that the PAA has contributed to increased income, consumption and self-esteem. There was a re-arrangement in their way of participating in the program, meanwhile some of their traditional practices were relegated. The program rules were re-signified and adapted locally. While growing solidarity has been observed among the gatherers, competition for the fruits has also increased.

Key-words: women, gatherers, commercialization, public policies, Food Purchase Program.

Classificação JEL: Z13.

\section{Introdução}

Para muitos estudiosos do tema, a comercialização de produtos pelos agricultores familiares ${ }^{7}$ é considerada um grande problema. Chayanov (1974 [1923]) sugeriu, há 90 anos, a verticalização dos processos de produção para facilitar a integração dos camponeses ao mercado, melhorar a sua posição na competição com os agricultores patronais e garantir a sua reprodução. Segundo vários cientistas, a relação com o mercado é um divisor entre diferentes grupos de agricultores familiares. Lamarche (1993, p. 18-19), por exemplo, afirma: “[...] nossa reflexão acerca da exploração familiar se organiza em torno de um eixo definido pelo grau de integração na economia de mercado" ${ }^{\prime 9}$. Abramovay (1992, p. 24) diz: "[...] são camponeses aqueles produtores familia-

7. Não fazemos aqui distinção entre as categorias campesinato e agricultura familiar. Para essa questão, ver Schmitz (2008).

8. A obra-prima de Chayanov foi primeiro publicada em alemão, em 1923, e apenas em 1925 em russo.

9. "É claro que concebemos esta integração em seu sentido mais absoluto, ou seja, tanto no plano técnico-econômico, quanto no plano sociocultural. Com efeito, é evidente que a um determinado grau de integração no mercado corresponda uma determinada relação com a sociedade de consumo, um determinado modo de vida e de representação" (LAMARCHE, 1993, p. 19). res marcados por uma inserção parcial em mercados incompletos". Não obstante, o critério "grau de integração ao mercado" é criticado por vários autores, como Fernandes (2002) e Costa (2000), que se distanciam da conceituação de Ellis (1993).

Tal distinção, por não se assentar em qualquer aspecto de natureza, mas se ancorar em características presentes em formas de existência da produção familiar rural, produz tanto equiparações quanto diferenças indevidas. [...] a integração do produto do trabalho camponês ao mercado "[...] nem sempre é, mas sempre poderá vir a ser parcial" (COSTA, 2000, p. 116-118).

Costa (2000, p. 115) enfatiza que "[...] campesinato supõe mercado". Mesmo os grupos sociais denominados "povos e comunidades tradicionais" não podem ser considerados produtores apenas de subsistência. Muitos deles produziram durante vários séculos para a exportação e adaptaram-se de forma flexível às estratégias do mercado mundial, como ocorreu na Amazônia (HOMMA, 2001) ${ }^{10}$.

10. A economia da Amazônia atendeu desde 1730 a demanda externa em diferentes ciclos: primeiro cacau, depois borracha, pau-rosa (para perfume), castanha-do-pará (ou castanha-do-brasil), juta, pimenta-do-reino, madeira de lei tropical, guaraná, entre outros. 
É ao tema da comercialização de um desses grupos que nos dedicamos neste artigo. Analisa-se aqui uma experiência de um grupo de mulheres, autodesignadas "catadoras de mangaba"11, na comercialização de frutas silvestres no âmbito do Programa de Aquisição de Alimentos (PAA) ${ }^{12}$. O campo de investigação foi o Povoado Pontal, no município de Indiaroba, estado de Sergipe. As denominadas "catadoras de mangaba" são portadoras de uma identidade coletiva que se deve ao uso comum de recursos com baixo impacto ambiental (CASTRO, 1997; MOTA, SILVA JÚNIOR e GOMES, 2003). Elas são também associadas ao Movimento das Catadoras de Mangaba de Sergipe (MCM) e, nos últimos anos, foram reconhecidas como sujeitos de direitos específicos (PORRO, VEIGA e MOTA, 2011). Em consequência, têm conquistado visibilidade social e iniciativas específicas para o grupo. Nem por isso deixam de enfrentar a diminuição dos recursos sobre os quais praticam o extrativismo em decorrência da destinação das áreas para outros fins (agricultura, infraestrutura turística e imobiliária e carcinicultura) e do corte das plantas por empresários e citadinos. É nesse contexto paradoxal de reconhecimento e de ameaça de expropriação dos recursos que se tem dado a participação no PAA, primeira experiência associativa de comercialização das catadoras no Brasil.

O pressuposto que orienta a nossa reflexão é: a participação no PAA possibilita o acesso substancial a recursos financeiros, pois preços considerados mais justos são pagos pelo programa com garantia de seu recebimento. Isso tem influenciado na autoestima das catadoras participantes e na ampliação da capacidade de consumo, como também constatado em outras análises (GRISA et al., 2009; SILIPRANDI e CINTRÃO, 2011). Ademais, essa participação contribui, entre outros aspectos, para: i) a reestruturação das rela-

\section{Hancornia speciosa Gomes.}

12. Instituído pelo artigo 19 da Lei 10.696/2003, o PAA é desenvolvido com recursos dos Ministérios do Desenvolvimento Social e Combate à Fome (MDS) e do Desenvolvimento Agrário (MDA). As diretrizes do PAA são definidas por um Grupo Gestor coordenado pelo MDS e composto por mais cinco Ministérios. ções entre aqueles que vivem do extrativismo, coletando frutos, comercializando, possuindo terra ou liderando as catadoras de mangaba; ii) a reorganização das rotinas de trabalho; iii) a crescente monetarização da atividade extrativista, o que acarreta rearranjos no modo de vida (BOURDIEU, 2010) ${ }^{13}$.

Neste quadro, as questões que orientam as nossas reflexões neste artigo são: 1) Como tem sido executado o programa no dia-a-dia da comunidade extrativista? 2) Quem são os atores envolvidos? 3) Como as catadoras lidam com o programa? 4) O PAA tem influenciado a relação das catadoras com o mercado (feirantes locais e intermediários), as relações entre as catadoras e o acesso aos recursos naturais? 5) Como são usados os recursos advindos do PAA? 6) Quais os significados atribuídos ao PAA localmente? 7) Como o PAA tem influído no modo de vida das catadoras?

Metodologicamente, optamos por um estudo de caso, que permite analisar a situação em profundidade. A pesquisa foi realizada entre 2008 e 2011. Foram utilizados procedimentos que permitem a coleta de dados qualitativos como a observação direta das reuniões e das atividades de coleta, de pós-coleta e de "entrega" dos frutos ao PAA. Dados foram buscados nas estatísticas oficiais relativas ao PAA. Entrevistas abertas e semiabertas para a coleta de dados primários foram realizadas com 36 pessoas, participantes ou não do programa, como lideranças, mediadores e catadoras de mangaba. De maneira geral, valorizamos os significados que as pessoas atribuem ao que vivem e ao que expressam por meio das suas "falas"14.

13. Esse livro, publicado em francês em 2008, foi organizado por Tassadit Yacine. Contém textos sobre as transformações na sociedade argelina durante a colonização e, principalmente, a Guerra da Argélia, que foram publicados por Bourdieu, na sua maioria no início dos anos 60 do século XX.

14. A "fala" é compreendida como uma das dimensões da constituição dos sujeitos e da produção de sentidos, por meio da qual é possível perceber os seus processos de identificação, de argumentação, de subjetivação e suas percepções da realidade (AGUIAR, 2011). Ademais, a "fala" é a matéria-prima a ser contrastada com a prática dos sujeitos sociais (MINAYO, 1994) observada em diferentes situações neste estudo de caso. 
O artigo está estruturado em cinco partes, além desta introdução. Na primeira, discute-se a questão da pobreza e a importância do reconhecimento, como também a problemática da criação de uma identidade coletiva me grupos sociais pobres. Na segunda, tratamos do PAA, enfatizando algumas das suas características, a abrangência e o debate crítico sobre o programa. Na terceira, refletimos sobre a experiência específica das catadoras de mangaba no programa, destacando a atuação dos mediadores e o reforço dos laços sociais preexistentes com a adaptação das regras do programa às necessidades prementes. $\mathrm{Na}$ quarta, analisamos a repercussão do PAA no processo de reconhecimento, na matriz de consumo e nos sonhos das catadoras de mangaba. Nas reflexões finais, são ressaltadas as virtudes do programa junto a algumas críticas, no intuito de contribuir para a sua melhoria, particularmente para grupos extrativistas que não têm acesso garantido aos recursos.

A eleição deste tema para a análise ampara-se no fato de que se trata da primeira experiência de comercialização coletiva da mangaba. Porém, são consideradas também as especificidades da atividade extrativista (sazonal, irregular) desenvolvida por famílias, nas quais o que é coletado serve, muitas vezes, tanto para o autoconsumo, quanto para a comercialização, quando a renda é utilizada para a aquisição de outros bens de consumo. Essas particularidades implicam dificuldades para a realização de cálculos econômicos, pela imprevisibilidade do acesso aos frutos. Assim, é necessário construir um quadro analítico sobre os modos de comercialização desenvolvidos por mulheres que dependem dos recursos naturais, associados à conservação ambiental. Mesmo assim, os extrativistas, historicamente, têm inserções descontínuas e desvantajosas no mercado e são, muitas vezes, dependentes de agentes externos (SHANLEY, LUZ e SWINGLAND, 2002; NAKAZONO, 2007).

\section{PAA, pobreza e reconhecimento}

No caso das catadoras de mangaba, trata-se, geralmente, de grupos desfavorecidos em vários aspectos. São mulheres pobres, sem terra, muitas vezes negras, líderes de família, com baixa ou nenhuma educação formal. A sua condição pode ser analisada a partir dos temas gênero, raça (entendida como uma construção social, segundo Costa, 2007), pobreza, distribuição fundiária etc.

A pobreza é entendida aqui como uma "[...] privação, que pode ser somente material ou incluir elementos de ordem cultural e social, em face dos recursos disponíveis de uma pessoa ou família. Essa privação pode ser de natureza absoluta, relativa ou subjetiva" (KAGEYAMA e HOFFMANN, 2006, p. 80). Geralmente, os estudos não determinam em que consiste essa privação, mas afirmam que ela depende do contexto social e da compreensão do que é necessário para uma vida (digna, na perspectiva dos próprios sujeitos). É, portanto, um fenômeno social, que pode ser analisado apenas dentro de um determinado quadro conceitual. A pobreza é considerada como uma desvantagem social séria (BRODBECK, 2005, p. 61).

Hoje, a pobreza é muitas vezes vista como uma falta de acesso a bens e serviços essenciais, como alimentação, saúde, vestuário e moradia. Esse entendimento já mostra um predomínio da perspectiva econômica. No entanto, outras variáveis além dessas são usadas para descrever a pobreza, como a saúde em geral, a expectativa de vida, a mortalidade infantil, a segurança alimentar e a educação, que afeta também a oportunidade de participar da riqueza social. Ainda outra variável pode ser a segurança na vida cotidiana. Em um sentido estrito econômico, muitas vezes, a compreensão da pobreza é reduzida à "renda monetária, mediada pela dimensão do mercado" (BRODBECK, 2005, p. 59).

$\mathrm{Na}$ literatura produzida pelas agências de desenvolvimento, em geral, distingue-se entre 
a pobreza absoluta e relativa, ambas determinadas a partir de orientações normativas. De acordo com o Banco Mundial, podem ser consideradas em pobreza absoluta as pessoas com renda inferior a US\$ 1,25 por dia (CEPAL, 2011). A pobreza relativa, no entanto, deve ser determinada em comparação com o contexto social das pessoas, considerando-se pobre quem tem menos que uma determinada porcentagem da renda média. A pobreza, na maioria dos casos, significa reduzida participação em atividades sociais - decisões políticas, programas culturais, lazer, consumo, entre outras.

Historicamente, a renda é um fenômeno relativamente novo para a maioria das pessoas. Até hoje, a sua existência não pode ser pressuposta para todas as pessoas, famílias ou grupos, como por exemplo, as populações que produzem essencialmente seus próprios meios de subsistência e que pouco praticam a troca comercial, como alguns povos indígenas da Amazônia. Uma grande parte das atividades das pessoas que vivem em sociedades industriais também não é mediada pelo mercado ou remunerada monetariamente, como por exemplo, as atividades desenvolvidas no interior dos grupos domésticos como a criação dos filhos, o processamento da comida, a limpeza da casa e o cuidado com as pessoas idosas e doentes ${ }^{15}$.

No caso das catadoras de mangaba, reflete-se sobre um grupo que vive da comercialização de uma grande parte de seus produtos, destacando a diferença entre a atividade extrativista de coleta e as atividades produtivas da agricultura que envolvem desde o preparo do terreno até a colheita. A renda média anual é baixa porque depende de produtos sazonais (mangaba e frutos do mar) que são coletados predominantemente em áreas de acesso livre ${ }^{16}$ e vendidos individualmente. Só raramente elas beneficiam o

15. O processo de imposição do princípio de desempenho individual e dos quadros normativos que definem as atividades que trazem "um benefício quantificável" para a sociedade na formação do capitalismo é descrito por Honneth (2003, p. 165-177).

16. As características das áreas de ocorrência de mangabeiras são tratadas em Schmitz, Mota e Silva Júnior (2009). fruto (além do processo chamado popularmente, a depender da região, "encapotar", "empalhar" ou "abafar a mangaba" tirada do galho para deixá-la amadurecer). A quantidade de frutos colhidos não pode ser aumentada além de um certo volume, porque essa "intensificação" não é possível no extrativismo ${ }^{17}$. $\mathrm{O}$ aumento da produtividade de trabalho, por exemplo, por meio de maior densidade das plantas por área, a redução dos caminhos a percorrer ou a aplicação de tratos culturais significa, em geral, a domesticação da planta, ou seja, a substituição da árvore nativa por uma árvore plantada em áreas perto da casa com espaçamento mínimo, o que exige também o acesso à terra, como observado no caso do açaí no Pará. Com base em dados de pesquisa de campo realizada em 2007, considerou-se uma "coleta satisfatória" do ponto de vista das entrevistadas a média de 1.700 kg de mangaba por ano por família (SCHMITZ, MOTA e SILVA JÚNIOR, 2011). Calculando-se o preço médio da mangaba em $\mathrm{R} \$ 0,50 / \mathrm{kg}$ e estimando-se que a atividade extrativista contribui com $0,70 \%$ da renda total, constata-se que a renda da família totaliza $\mathrm{R} \$ 1.214,00$ por ano. Por mês, é de $\mathrm{R} \$ 101,20$, ou $26,6 \%$ do salário mínimo (R\$ 3,37/dia ou US\$ 1,73/dia, em 4 de setembro de 2007). Mesmo considerando-se as margens de erro dessa estimativa, pode-se afirmar que a situação das catadoras de mangaba aproxima-se daquela considerada pelos planejadores do desenvolvimento como de pobreza absoluta.

Recentemente, a pertença ao MCM desencadeou entre as mulheres um processo de identificação coletiva como catadoras de mangaba. Analisando-se os resultados da atuação do MCM nos primeiros dois anos da sua existência, constata-se que a maior conquista é o reconhecimento, local e nacionalmente, da identidade como catadora de mangaba. "O sucesso, para muitos movimentos, pode consistir mais em estabelecer uma identidade coletiva do que conquistar sucesso político" (Tarrow, 2009, p. 205). Essa conquista vale

17. Sobre as limitações do extrativismo, ver Homma (1993) e nossos comentários (SCHMITZ, MOTA e SILVA JÚNIOR, 2009). 
tanto para o público externo (instituições, opinião pública), quanto para os membros do MCM.

A criação de uma identidade coletiva é crucial para o desenvolvimento de ações coletivas objetivando melhorar a situação, pois esse processo contribui para superar a fragmentação e o isolamento. Porém, assumir a identidade de um grupo de pessoas pobres pode ser problemático para alguns, especialmente quando essa identidade é sentida como vergonhosa. Esse problema existe em grupos de desempregados estudados por Fillieule (1993) na França, em grupos de trabalhadores sem-terra no Brasil ${ }^{18}$, e entre as catadoras de mangaba em determinado estágio da trajetória do grupo. No caso da participação nas atividades do Movimento dos Trabalhadores Rurais Sem-Terra (MST), isso significa assumir apoderar-se ${ }^{19}$ ou invadir o que é considerado de domínio privado (MARTINS, 2003).

Nos últimos anos, o tema "reconhecimento" foi trazido à tona no debate acadêmico ${ }^{20}$, o que tem muitas vezes deixado em segundo plano a questão da distribuição justa dos bens socialmente produzidos. Fraser (2003), portanto, acredita que ambos os aspectos devem ser igualmente considerados como dimensões da justiça. No caso das catadoras de mangaba, percebe-se que o reconhecimento que elas têm experimentado desde a criação do MCM, em 2007, não é suficiente. A reação de seus adversários à mobilização das mulheres resultou no impedimento do acesso aos recursos em muitas áreas anteriormente abertas

18. José de Souza Martins constata esse problema no caso dos sem-terra que recebem de um apoio organizacional muito mais forte do MST que as catadoras de mangaba do MCM. Mesmo assim, Martins (2003, p. 135) afirma sobre os líderes do MST: "[...] conseguiram mobilizar os pobres [...], mas não conseguiram convencê-los da legitimidade dessa mobilização". Conclui que os assentados querem reformar a própria imagem.

19. A relação das catadoras com os recursos pode ser caracterizada pelas palavras de uma catadora: "A terra pode ter dono, mas a mangaba é de ninguém!"

20. Honneth (2003, p. 148-159) destaca a falta de reconhecimento como uma causa central da percepção de injustiça social, que, segundo o autor, está na base do desenvolvimento de resistência e protesto. Porém, rejeita que o reconhecimento seja apenas um fenômeno novo nas lutas de movimentos sociais. para todas elas. Logo, se, por um lado, aumentou o reconhecimento individual e público do grupo, por outro, os seus meios de vida desvanecem e sua situação econômica se agrava. Mesmo a aprovação de uma lei estadual pela Assembleia Legislativa do estado de Sergipe ${ }^{21}$, que reconhece as catadoras de mangaba como um grupo culturalmente diferenciado e estabelece o autorreconhecimento como um critério do direito, não implica, por si mesma, neste momento, uma alteração substancial da situação econômica das mulheres.

Iniciativas como o Programa Bolsa Família e o PAA, ambos do governo federal, caracterizados como medidas de redistribuição, têm, portanto, grande impacto na vida das catadoras, por causa de sua pobreza. Nesse contexto, levanta-se a questão de saber se tais programas contribuem também para o reconhecimento mútuo entre as mulheres e pelos outros ou se trazem o efeito oposto de estigmatizar quem os usa, como é frequentemente o caso da assistência social. De fato, uma questão-chave para a avaliação das políticas públicas consiste em verificar se elas promovem a solidariedade ou se estigmatizam aqueles que delas precisam (FRASER, 2003, p. 116).

As duas medidas são diferentes por sua natureza. Enquanto o Bolsa Família é um programa de transferência direta de renda com condicionalidades (comprovação de matrícula escolar e de vacina das crianças), que beneficia famílias em situação de pobreza e de extrema pobreza, o PAA é uma estratégia que prevê o pagamento de um preço justo para um produto que é produzido de acordo com critérios definidos. Portanto, é provável que o PAA, além do efeito econômico, tenha também um impacto sobre o reconhecimento das mulheres entre si e pelos outros. Não se trata, portanto, do exemplo convencional da assistência social. Porém, o efeito de cada uma dessas estratégias pode ser avaliado apenas pelo estudo da situação concreta.

21. Lei n. 7.082, de 16 de dezembro de 2010. 


\section{Considerações sobre o PAA}

Segundo documentos da Companhia Nacional de Abastecimento (CONAB, [2007]), o $\mathrm{PAA}^{22}$ foi criado no âmbito do governo federal em 2003 como uma das ações estruturantes do Programa Fome Zero. A emergência desse tipo de iniciativa, segundo Grisa et al. (2009), deu-se num momento de confluência dos debates sobre a problemática da segurança alimentar e nutricional nas últimas três décadas e do reconhecimento da importância da agricultura familiar no Brasil com a criação do Programa Nacional de Fortalecimento da Agricultura Familiar (Pronaf) em 1996 e, mais recentemente, com a promulgação, em 2006, da Lei n. 11.326, que estabelece as diretrizes para a formulação da política nacional da agricultura familiar e de empreendimentos familiares rurais, entre os quais os extrativistas.

O programa tem como objetivo central "garantir o acesso aos alimentos em quantidade, qualidade e regularidade necessárias às populações em situação de insegurança alimentar e nutricional e promover a inclusão social no campo por meio do fortalecimento da agricultura familiar" (CONAB, [2007]). Com essa finalidade, o programa apoia simultaneamente a compra e venda de alimentos dos agricultores familiares ${ }^{23}$ com incentivos, inclusive de participação nos circuitos formais de comercialização, visando estimular a produção de alimentos na agricultura familiar e permitir a comercialização no mercado institucional (DELGADO, CONCEIÇÃO e OLIVEIRA, 2005). Tendo em conta essa finali-

22. Instituído pelo artigo 19 da Lei n. 10.696, de 02 de julho de 2003, e regulamentado pelo Decreto n. 4.772, de 02 de julho de 2003.

23. Segundo a Lei n. 11.326, de 24 de julho de 2006, que estabelece as diretrizes para a formulação da Política Nacional da Agricultura Familiar e Empreendimentos Familiares Rurais, os extrativistas que atendam simultaneamente aos requisitos previstos nos incisos II, III e IV (utilizar predominantemente mão de obra da própria família nas atividades econômicas do seu estabelecimento ou empreendimento, ter renda familiar predominantemente originada de atividades econômicas vinculadas ao próprio estabelecimento ou empreendimento e dirigir seu estabelecimento ou empreendimento com sua família) são considerados agricultores familiares. dade, destaca-se, no escopo do PAA, a aquisição direta de alimentos de produtores familiares com dispensa de licitação para a doação a instituições e pessoas em situação de insegurança alimentar e nutricional ou para a formação de estoques estratégicos e para o abastecimento do mercado institucional de alimentos, que compreende as compras governamentais de gêneros alimentícios para fins diversos. O programa permite que os agricultores familiares estoquem seus produtos para serem comercializados a preços mais justos (SILIPRANDI e CINTRÃO, 2011).

Passada mais de uma década após a criação do PAA, analistas tecem considerações sobre o programa a partir de diferentes perspectivas, ressaltando a atuação do programa em um campo de ação que é demarcado, de um lado, pelas ações da política agrícola de formação de estoques e compra de produtos agrícolas, realizadas pela Conab, e, de outro, pelas iniciativas do Programa Fome Zero, que buscam ampliar o acesso a alimentos mediante mecanismos de subvenção às compras e a redistribuição às entidades que trabalham com populações em situação de risco ou de vulnerabilidade alimentar, como asilos, orfanatos, escolas, creches, entre outras (MÜLLER, FIALHO e SCHNEIDER, 2007);

Reconhecidamente, o programa promove mudanças importantes na matriz produtiva e de consumo das unidades de produção familiares, fortalecendo, inclusive, a sua autonomia ante as adversidades e estimulando o aproveitamento de frutas nativas, a conexão entre a produção e o consumo local, a recuperação dos preços regionais, a independência de produtores ante o atravessador, a criação de novos mercados (feiras agroecológicas, por exemplo), entre outros aspectos positivos (GRISA et al., 2009).

Em outro âmbito, é constatado que a inovação institucional do programa tem facilitado a relação entre produtores e consumidores, inclusive quanto ao reconhecimento da importância de um grupo para o outro (DORETTO e MICHELLON, 2007). Mesmo assim, os estudiosos reconhecem que "Os arranjos institucionais são resultados da articulação de diferentes atores no tempo e 
no espaço, conferindo-lhes especificidade local, dadas as características dos participantes do processo". Ou seja, "os arranjos institucionais são específicos e distintos" (MÜLLER, FIALHO e SCHNEIDER, 2007).

Estudiosos afirmam que é evidente a maior participação das mulheres agricultoras no PAA, mesmo que de forma anônima em muitos casos, frequentemente pelo fato de os homens serem considerados "o cabeça da DAP"24 em decorrência de uma série de motivos. Siliprandi e Cintrão (2011) destacam a valorização, pelo programa, do trabalho feminino nas modalidades com doação simultânea, "ao criar canais de comercialização para seus produtos a um preço justo e com formas de operação que atendem às suas necessidades (entregas parceladas, constantes, em pequenas quantidades)" (SILIPRANDI e CINTRÃO, 2011, p. 22).

Finalmente, Chmielewska, Souza e Lourete (2010) ressaltam que o PAA, particularmente em Sergipe, tem provocado mudanças nas práticas produtivas e organizacionais orientadas para o mercado. Entretanto, evidenciam a preocupação quanto às práticas comerciais, afirmando que "elas não estão necessariamente levando a outros mercados" (CHMIELEWSKA, SOUZA e LOURETE, 2010, p. 36). Os autores temem que, no caso do encerramento do PAA, os agricultores voltem a uma situação muito próxima daquela vivenciada anteriormente.

Revisando a literatura, constata-se que, em 2010, 94.398 famílias de agricultores familiares, incluindo também comunidades tradicionais, povos indígenas e assentados, participavam do programa em todo o País. Em Sergipe, foram 4.028, sendo 3.870 agricultores familiares e 158 assentados. Esses números são maiores do que os

24. Declaração de Aptidão ao Pronaf. Siliprandi e Cintrão (2011, p. 5) afirmam que a DAP foi criada em 2003 pelo MDA, para identificar os agricultores e agricultoras familiares que poderiam ter acesso aos créditos de investimento e custeio no âmbito do Pronaf. É fornecida à família agricultora que tem dois titulares (mais frequentemente - mas não necessariamente - o marido e a mulher), podendo ser incluídos os demais membros que trabalham na unidade familiar, identificados com base em seus Cadastros de Pessoas Físicas (CPF). registrados para o Maranhão, Piauí, Rio Grande do Norte, Paraíba e Alagoas (CONAB, [2011]).

A "geografia" do PAA e sua distribuição por regiões mostram que a região Nordeste foi a que mais recebeu recursos do PAA no período de 2003 a 2007, totalizando 54\%. A região Sul foi a segunda, com $18,7 \%$, seguida pelo Sudeste $(17,9 \%)$, Norte $(6,8 \%)$ e Centro-Oeste $(2,7 \%)$. Os autores destacam que os estados com maior insegurança alimentar têm recebido menos recursos, atribuindo esse fato à dificuldade de mobilizar os recursos necessários ao funcionamento do PAA, tanto pela limitada circulação da informação e pelo problema do acesso a serviços, quanto pelas dificuldades de transporte dos produtos para um mesmo lugar com certa regularidade (GRISA et al., 2009; CONAB, [2011]).

Em se tratando especificamente da mangaba no PAA, de acordo com a Gerência de Acompanhamento e Controle das Ações da Agricultura Familiar (Gecaf) ${ }^{25}$ da Conab, em 2010 e 2011, a maior parte da polpa e do fruto entregue foi proveniente do Nordeste, sobretudo de Sergipe, responsável por $72 \%$ dos recursos destinados à compra de mangaba pelo programa em 2010 (Quadro 1).

No Povoado Pontal, onde foi realizado o estudo de caso aqui descrito, as catadoras têm acesso à Compra Antecipada Especial da Agricultura Familiar (Caeaf) ${ }^{26}$, com doação simultânea a instituições localizadas no município ou

25. Informação pessoal fornecida pelo Sr. Gustavo Lund Viegas, gerente de acompanhamento e controle das ações da agricultura familiar da Conab, em 21 de outubro de 2011.

26. A Caeaf destina-se à aquisição de produtos de origem agrícola, pecuária e extrativa, oriundos da agricultura familiar, visando a formação de estoques ou a doação às populações em situação de risco alimentar atendidas por programas sociais de caráter governamental ou não governamental. Os produtores beneficiários deverão estar organizados em grupos formais e estar enquadrados nos critérios estabelecidos pelo programa. Nos casos de doação simultânea, a entrega dos produtos deverá obedecer a um cronograma de entregas apresentado na Proposta de Participação. O controle social das doações dar-se-á por meio do envolvimento do Conselho de Segurança Alimentar (municipal ou estadual) ou de um organismo similar. Essa modalidade também é operacionalizada pela Conab. 
Quadro 1. Compra de mangaba pelo Programa de Aquisição de Alimentos em 2010 e 2011

\begin{tabular}{|c|c|c|c|c|c|}
\hline Ano & UF & Município & Produto & Valor (R\$) & Quantidade (kg) \\
\hline 2010 & MG & Pai Pedro & Mangaba & $4.500,00$ & 1.500 \\
\hline 2010 & PB & Pitimbu & Polpa de mangaba & $25.974,00$ & 5.772 \\
\hline 2010 & RN & Ceará-Mirim & Mangaba & 749,70 & 441 \\
\hline 2010 & RN & Extremoz & Polpa de mangaba & $12.000,00$ & 3.000 \\
\hline 2010 & SE & Indiaroba & Mangaba & $40.950,00$ & 27.300 \\
\hline 2010 & SE & Santa Luzia do Itanhy & Polpa de mangaba & $89.600,00$ & 32.000 \\
\hline 2011 & PB & Pitimbu & Polpa de mangaba & $1.490,00$ & 298 \\
\hline 2011 & PE & Ibimirim & Mangaba & $1.080,00$ & 1.000 \\
\hline 2011 & RN & Ceará-Mirim & Polpa de mangaba & $1.500,00$ & 300 \\
\hline 2011 & RN & Touros & Polpa de mangaba & $4.500,00$ & 1.000 \\
\hline
\end{tabular}

Fonte: Informação fornecida pelo representante da Gecaf da Conab, em 2011.

nas proximidades ${ }^{27}$. A instituição que tem abrigado as catadoras é a Cooperativa de Produção, Comercialização e Prestação de Serviços dos Agricultores Familiares de Indiaroba e Região (Cooperafir), afiliada à Associação de Cooperação Agrícola dos Assentados da Região Sul (Ascosul).

Conforme a orientação do PAA, as condições para fazer parte do programa são a afiliação à cooperativa, a propriedade da DAP e a identificação da catadora como extrativista pelo mediador local $^{28}$ do PAA. É este último que, voluntariamente, organiza as entregas, pesa os frutos, anota as quantidades de cada catadora e realiza todas as tarefas burocráticas em relação às demais instituições. Um mediador regional (vereador e membro da Ascosul) atua como articulador quanto à destinação dos frutos e contatos com a Conab. A divulgação de datas de eventos alusivos ao PAA, particularmente as "entregas", são feitas pelas lideranças e pelas próprias catadoras.

27. Em 2010, as instituições atendidas foram as seguintes: Associação de Moradores do Povoado Convento, Associação do Menor Aprendiz, Associação dos Produtores Rurais do Povoado Félix, Associação pela Cidadania dos Pescadores de Terra Caída, Associação Sergipana de Desenvolvimento Comunitário e Resgate da Cidadania.

28. Presidente da associação de moradores do Povoado Pontal e agente de saúde.

\section{O PAA no Povoado Pontal: a atuação dos mediadores e o reforço dos laços sociais preexistentes}

Como o PAA condiciona a participação dos seus beneficiários a uma organização formal, apenas o grupo de catadoras do Pontal estava apto a participar do programa em 2007. Ali, desde 2003, a articulação entre catadoras e atores externos, cujo interesse comum era o acesso aos recursos nativos, favoreceu uma aliança que atraiu a atenção de mediadores sociais e políticos desejosos de estabelecer a relação entre o que consideravam as demandas do grupo em evidência (comercialização dos frutos oriundos do extrativismo) e os serviços públicos - o que faria parte do seu papel de acenar com ações que tragam vantagens e assegurem certo dinamismo à vida social daqueles que por eles são representados (WIGGERS, 2010).

Segundo as entrevistadas, os mediadores ${ }^{29}$ foram responsáveis pela divulgação do PAA no Pontal em 2006. Após reunião com um grupo de 28 catadoras de mangaba, eles obtiveram a con-

29. Um vereador membro da Cooperativa de Produção, Comercialização e Prestação de Serviços dos Agricultores Familiares de Indiaroba e Região (Cooperafir) - que na ocasião participava do PAA com agricultores familiares com 10 produtos: abacaxi, banana, batata-doce, cebolinha, coco verde, coco seco, coentro, laranja, maracujá, raiz de mandioca com e sem casca - e o presidente da Associação de Moradores do Povoado Pontal. 
cordância delas para formalizar uma proposta à Conab visando a inclusão da mangaba no PAA. Entretanto, apenas seis catadoras sentiram segurança para afiliar-se ao PAA em 2007. As demais que haviam participado da reunião e sabiam da existência do programa sentiam-se inseguras: "porque a gente não conhecia outros grupos que tivessem fazendo entrega" (M.J.C.S., 33 anos); "nós tinha medo que os atrasos no pagamento comprometessem as necessidades" (E.M.C., 46 anos). Outras revelavam medo de participar de mais um programa do governo federal e perder o seguro defeso ${ }^{30}$, renda considerada muito importante para a subsistência das famílias no período da proibição da pesca (defeso).

O primeiro grupo a participar do PAA foi constituído por seis catadoras interligadas por laços de amizade e parentesco, pois duas eram irmãs, duas eram cunhadas e duas eram amigas. Nota-se, nessa composição, o lugar de destaque das relações de parentesco e de proximidade na efetivação local do PAA. Segundo informam os mediadores, $8.000 \mathrm{~kg}$ de mangaba foram "entregues", o que equivale a cerca de $\mathrm{R} \$ 12.000,00$ distribuídos entre as seis catadoras. Segundo elas, esse recurso destinou-se à aquisição de eletrodomésticos para as suas residências e ao pagamento de contas em atraso.

Na segunda "entrega" no final de 2007, mais 14 catadoras de mangaba afiliaram-se ao PAA, somando 20 formalmente cadastradas. Embora outras catadoras expressassem o desejo de se cadastrar naquele ano, não conseguiram adequar-se aos prazos. Assim, as já cadastradas entregaram tanto os seus frutos, como os das demais, repartindo o dinheiro equivalente por ocasião do recebimento. A iniciativa extrapolou o previsto pelo PAA, mas já era uma prática comum na história do grupo. Com efeito, muitas vezes uma

30. Programa de política pública para garantir renda de subsistência ao pescador no período do defeso. Além disso, a política do seguro defeso estimula a criação do que se pode chamar uma consciência ambiental de preservação dos peixes, crustáceos e moluscos, pois, ao proibir a pesca no período do defeso, contribui para a preservação da complexa e rica biodiversidade (MOREIRA, SCHERER e SOARES, 2010). catadora dirigia-se à feira com frutos dela e das vizinhas para negociar. Esses arranjos reforçavam a solidariedade e a coesão do grupo, além de diminuir a concorrência no decorrer das vendas com diferentes pessoas oferecendo a mesma fruta.

A situação descrita foi estratégica para lidar com um empecilho burocrático que impedia a participação de todas as catadoras no PAA por causa da falta da DAP. Assim, cada catadora cadastrada abriga outra no seu nome, porque elas sabem que o montante advindo do PAA é muito significativo. Isso pode parecer "incorreto", "irregular", mas, na realidade, é a evidência de um tecido social forte, de uma capacidade coletiva de resistir, da demonstração do desejo e da necessidade de permanecer na atividade. Por isso, essas práticas são vistas pelas catadoras como normais. Da mesma forma, os mediadores e nós, pesquisadores, também as aceitamos, porque somos sabedores da condição de insegurança social que atinge as catadoras. Sabe-se, também, que não há discordâncias entre elas sobre esse tema. Por tudo isso, propõe-se que os legisladores do PAA tomem esse exemplo como tema de reflexão por ocasião do redimensionamento do programa.

Em 2010, a maior parte das catadoras formalizou sua afiliação ao PAA, totalizando 30 , das quais aproximadamente $90 \%$ tinham DAP. Essa situação contrasta com aquela descrita por Siliprandi e Cintrão (2011) para o Brasil, qual seja, a participação anônima das mulheres. Os homens eram titulares da DAP, tanto por práticas discriminatórias de membros da burocracia estatal que emite a DAP, como pelas desigualdades de gênero. No caso das catadoras de mangaba no Pontal, ter a DAP em seu nome reforça elementos da conformação da sua identidade coletiva, segundo a qual o trabalho no extrativismo da mangaba é de domínio das mulheres (MOTA et al., 2008). Uma entrevistada afirmou: "nem fica bem um homem se abaixando pra pegar mangaba".

O aumento da participação das mulheres no PAA está demonstrado no Quadro 2.

Embora o PAA seja positivamente reconhecido pelas catadoras de mangaba, elas encontram dificuldade para caracterizar o programa, 
Quadro 2. Número de catadoras afiliadas ao Programa de Aquisição de Alimentos (PAA) por ano e total de frutos entregues entre 2007 e 2011, no Povoado Pontal, em Indiaroba (SE)

\begin{tabular}{|c|c|c|c|c|}
\hline \multirow{2}{*}{ Ano } & Número de catadoras afiliadas ao PAA & Total de frutos entregues & $\begin{array}{c}\text { Valor estimado de recursos } \\
(\mathbf{k g})\end{array}$ \\
\cline { 2 - 3 } & Oficialmente & Na prática** & 8.000 & 8.000 \\
\hline 2007 & 06 & 06 & 9.000 & 9.000 \\
\hline $2008^{* * *}$ & 06 & 14 & 10.000 & 15.000 \\
\hline 2009 & 20 & 20 & 27.300 & 40.950 \\
\hline $2010^{* * * *}$ & 20 & 30 & 50.000 & 75.000 \\
\hline 2011 & 30 & 50 & 0 & \\
\hline
\end{tabular}

* Em 2007 e 2008 o preço da mangaba praticado no PAA foi R\$1,00/kg. A partir de 2009, foi R\$1,50/kg. A mudança do valor foi influenciada pela argumentação das catadoras dirigida ao dirigente da Conab por ocasião da reunião dos extrativistas em Brasília, em 2009.

** Na prática refere-se ao número de catadoras agrupadas em torno de alguém da família e que juntam os frutos para "entregar" como também o faziam no passado dividindo os recursos por ocasião do recebimento.

*** Estimativa com base na tendência observada e nas informações orais das catadoras entrevistadas. Os demais anos foram calculados a partir do controle do articulador local das "entregas" individuais.

**** Doados para a associação de moradores do Povoado Convento, a associação do menor aprendiz, a associação dos produtores rurais do Povoado Félix, a associação pela cidadania dos pescadores de Terra Caída, a associação sergipana de desenvolvimento comunitário e resgate da cidadania.

Fonte: Pesquisa de campo realizada de 2009 a 2011.

como também foi observado por Jalil (2010) em outro contexto ${ }^{31}$. Quanto ao funcionamento local do PAA, as catadoras demonstraram conhecer a sua participação, os documentos exigidos, os dias de recolhimento dos frutos, a destinação dos frutos e os preços pagos. É importante observar que elas chamam a atenção para uma relação que foi incentivada pelo PAA - a relação entre a extrativista e quem consome ou, em outros termos, entre o produtor e o consumidor. Para elas, essa relação motivou uma preocupação com a qualidade das frutas a serem entregues, pois as catadoras estão informadas do poder dos receptores em influenciar a continuidade do projeto, ou não, a depender da satisfação.

Quando questionadas sobre o que é o PAA, algumas catadoras afirmaram: "é um projeto que a gente entrega as mangabas" (M.J.C.S., 33 anos); "um grupo de pessoas que tenta ajudar, uma cooperativa que tenta passar algo de bom a outros que não têm" (S.A.S., 35 anos); "ajuda no desenvolvimento, um projeto" (A.P., 34 anos); "é um projeto importante, porque é dele que a gente tira o nosso sustento. Sabe que o dinheiro é garantido" (A.M.S.S., 25 anos). "Projeto" é uma palavra mencionada em todos os depoimentos, o que revela um vocabulário influenciado por

31. No estudo do autor em Esperantina (PI) e Mirandiba (PE), as mulheres tiveram dificuldade em apontar quem são os atores do Estado e da sociedade civil que constituem o PAA. atores externos e demonstra a iniciativa do próprio grupo para dialogar com pessoas de outros universos.

\subsection{PAA: garantia de preço, maior disputa pela fruta}

Historicamente, o extrativismo da mangaba é praticado pelas catadoras em quatro formas: i) em áreas de acesso livre, que podem ser áreas privadas abandonadas ou do Estado (devolutas); ii) em pequenos, grandes e médios estabelecimentos privados mediante uma permissão condicionada a vínculos de amizade, conhecimento ou parentesco; iii) em pequenos estabelecimentos herdados de parentes nos quais vivem com a família; iv) em pequenos, médios e grandes estabelecimentos privados mediante compra ou outros acordos (parceria, meia) que incluem pagamento. Esses modos de acesso, em muitos casos, são postos em prática simultaneamente. Entretanto, é unanimidade entre os entrevistados que, na última década, o acesso aos recursos tem diminuído de forma crescente em decorrência de atividades e iniciativas de políticas públicas que acarretam o corte das plantas (estradas, pontes, carcinicultura, agricultura, infraestrutura turística, casas de veraneio).

De acordo com a nossa análise, também influenciou nesse processo a mobilização das 
catadoras e a conquista de políticas públicas específicas. Os donos de terra revelam insegurança porque têm medo de desapropriações por interesse social. Assim, se, por um lado, o reconhecimento das catadoras como sujeitos de direitos específicos ocorre nas esferas de negociação, por outro, diminui o acesso aos recursos naturais dos quais dependem localmente para continuar a pôr em prática os direitos específicos conquistados.

Em se tratando do Pontal, Rocha (2011) constatou que, de um total de 31 propriedades com mangabeiras, a entrada das catadoras para a coleta está proibida em 18 (58\%), inclusive com ameaças de violência física em quatro delas. Em nove (30\%), a entrada é permitida. Em três propriedades $(10 \%)$, as mangabeiras foram cortadas em 2010 para evitar a entrada das catadoras ou para desenvolver outra atividade. Em uma propriedade, informações não foram obtidas. Segundo relatos, até 2003, o acesso das catadoras aos estabelecimentos do Pontal era livre, ou seja, um direito de todos. Entretanto, já se registravam insatisfação e proibições de alguns proprietários, como também iniciativas das catadoras para resistir a proibições (MOTA, SILVA JÚNIOR e GOMES, 2003; SILVA JÚNIOR, MOTA e GOMES, 2003). Mais recentemente, alguns proprietários têm investido, inclusive, em vigilância armada, porque temem ter as terras desapropriadas em decorrência da implantação de uma Reserva Extrativista (Resex). Cabe lembrar que um estabelecimento com um importante número de plantas (4.500) persiste com acesso aberto, e sua proprietária não parece ter dúvida da importância dele para as catadoras que não têm terra.

É nesse quadro de diminuição do acesso e dos próprios recursos que se concretiza a possibilidade de obter preços melhores para as catadoras. Paradoxalmente, se o preço é garantido, o acesso ao produto não o é, diferente dos agricultores, que têm na condição de acesso à terra a possibilidade de diversificação, de previsão de colheitas e de retorno financeiro no PAA (GRISA et al., 2009). Essas particularidades implicam diferentes sentidos do PAA para os dois grupos em relação ao futuro, particularmente quanto ao estabele- cimento de práticas orientadas para o mercado, pelas (in)certezas da disponibilidade do fruto. Em comum, os grupos têm gozado de maior autonomia quanto aos canais de comercialização, ao preço justo e à garantia do recebimento.

Na prática, o PAA é bem diferente para as extrativistas quando comparadas aos agricultores, porque elas dependem de produtos específicos para ter um volume que justifique a "entrega", têm dificuldade de previsão em decorrência da falta de garantia de acesso aos recursos e necessitam rearranjar o que fazem para compensar a escassez. Nesse sentido, a rotina de um segmento das catadoras que participam do PAA tem sido bem alterada, e os dias que antecedem a "entrega" são intensamente dedicados à coleta da mangaba.

"Quando cato mangaba, deixo tudo extra, como mangue, tarefas domésticas. Deixo de fazer as coisas para ir catar mangaba. Quando vou pra Terra Caída ou Preguiça, aí é que deixo mesmo de fazer outras tarefas. O mangue dá doença, dor na perna, calor da lama. A vantagem é que a gente não perde, não vai para feira e ter que jogar fora quando tem muita mangaba. Já cata e entrega aqui mesmo em Pontal e o tanto que catar entrega. Já tem valor certo. Não se submeter a vender num preço mínimo quando tem muita mangaba. Não perde mais a mangaba. E antigamente os compradores de fora não levavam as maduras e eu perdia" (S.A.S., catadora de mangaba, 35 anos).

"Quando cato mangaba, deixo o mangue porque não dá tempo de ir e a pessoa ganha mais na mangaba" (E.M.C., catadora de mangaba, 46 anos).

"Quando não tá na safra, aí eu vou pro mangue" (A.C.O.S., catadora de mangaba, 22 anos).

Outras, entretanto, preferem conciliar o extrativismo da mangaba com outras atividades, sem deixar de reconhecer que os recursos advindos do PAA são prioritários:

“Não deixo de ir no mangue porque também ganha mais dinheiro. Porque [a mangaba] é 
aquela coisa certa, que a gente entrega toda a quantidade para uma pessoa certa" (M.J.C.S., catadora de mangaba, 33 anos).

"Não deixo as tarefas na semana da entrega porque vou e volto cedo. As cocadas faço no final de semana e ainda faço as tarefas de casa" (A.M.S.S., catadora de mangaba, 25 anos).

Seja qual for o arranjo entre as atividades, a coleta no manguezal fica em segundo plano, porque as catadoras priorizam o que dará retorno garantido, transformando arranjos tradicionalmente praticados e reduzindo a diversidade de atividades e de produtos oriundos da coleta. Isso tem influenciado tanto na dieta - com menor disponibilidade dos produtos do mangue e maior consumo daqueles provenientes de compra no mercado (carne e frango, por exemplo) - quanto na disponibilidade e no grau de exploração dos recursos naturais.

Em consequência, algumas catadoras afirmam sair nas primeiras horas da manhã, porque, "se não acordar cedo, não tira mangaba", em razão da grande concorrência. Algumas poucas buscam regiões distantes na outra margem do rio Real $^{32}$, com possibilidade de encontrar mais frutos. A maioria das catadoras, entretanto, permanece nas imediações do povoado há anos e afirma não gostar de ir a outros lugares. Assim, coletam em pequenas áreas de ocorrência de mangabeiras em terras da família, em áreas de acesso livre ou mediante acordo com alguns proprietários, mas também em estabelecimentos em conflito, quando percebem não haver vigilância. A frequência das idas das catadoras ao campo varia de uma a três vezes por dia, durante a semana que antecede a "entrega" ao PAA.

Qualquer que seja o lugar onde coletam, todas as catadoras entrevistadas afirmaram estar naquele momento preocupadas em obter a maior quantidade possível de mangaba em decorrência do pagamento justo e garantido. Por isso, muitas

32. Muitas vezes é preciso usar um barco, e elas temem acidentes. Temem também que o terreno esteja sendo vigiado por caseiros que as ameaçam. delas estavam envolvendo outras pessoas (filhos e parentes) na coleta e aumentando o raio de atuação, o número de idas aos campos e diversificando os horários.

Em entrevistas abertas para esta pesquisa, houve relatos de situações em que, na ânsia de finalizar a tarefa, membros da família quebraram galhos e retiraram frutos verdes. Esses eventos contrastam com os registros anteriores da pesquisa, em que relatos recorrentes atestam a tradição quanto ao cuidado com uma socialização de conhecimentos tradicionais no grupo primário amparada no respeito do uso sustentável dos recursos, tradição que é transmitida oralmente e demonstrada pelos mais experientes. Como disse uma catadora, "elas ficam com usura para coletar mais e 'entregar', que acabam catando de qualquer jeito e deixando as plantas quebradas". Fatos dessa natureza têm provocado localmente um conflituoso debate com acusações recíprocas, pois as catadoras de mangaba percebem que, caso se agrave essa situação, existe o risco de diminuição da produtividade das plantas, o que pode gerar uma espécie de corrida para chegar primeiro, que tende à superexploração ou ao extrativismo predatório, inclusive com a coleta de frutos verdes.

Segundo as entrevistadas, novas regras precisam ser estabelecidas para a situação, porque as anteriores, que eram claras quanto aos cuidados com as plantas, não têm sido respeitadas suficientemente. Diante da possibilidade de preços justos e garantidos, na atual condição de precariedade, as pessoas tentam melhorar a sua situação, particularmente porque sabem que o acesso aos recursos está diminuindo.

Duas catadoras de mangaba não afiliadas ao PAA afirmaram que não têm interesse no programa, mas sabem do seu funcionamento, porque têm vizinhas, primas e cunhadas que dele participam. Em sintonia com a chamada autonomia relativa do campesinato no controle do ritmo e da intensidade de sua força de trabalho, elas acreditam que, para fazer a "entrega", têm de coletar sempre e querem fazê-lo ocasionalmente, apenas quando têm necessidade. Preferem 
vender para um atravessador ou alguém que encomenda. Perceberam também que, com o funcionamento do PAA no Pontal, mais pessoas passaram a coletar a fruta: por isso, acreditam que não existe muita mangaba para "entregar" semanalmente. Uma dessas catadoras acha ainda que coletar mangaba é trabalhoso e prefere trabalhar na "maré" (no manguezal), coletando caranguejo e aratu, porque são mais lucrativos. Além disso, revela gostar da facilidade de comercializar com o atravessador que vai a sua casa para comprar os frutos. Apesar do estímulo recebido do PAA, as catadoras também divergem nas suas opções e algumas preferem manter o ritmo de trabalho habitual e inclusive a relação com antigos parceiros para a comercialização.

\subsection{A "entrega" dos frutos no PAA: um novo momento de reconhecimento, sociabilidade e diferenciação}

Na safra de dezembro de 2010 a fevereiro de 2011, em quase todas as sextas-feiras, ocorreram "entregas" de mangaba ao PAA do Pontal, totalizando dez. Constatou-se que essas "entregas" têm representado um novo espaço e um novo tempo de sociabilidades com diferentes sentidos, como interação lúdica, controle social da devastação dos recursos e demonstração do reposicionamento das catadoras numa dada organização social. Ali, as catadoras entregaram os frutos publicamente ao mesmo tempo, por um mesmo preço e para um mesmo receptor em contraste com as ocasiões nas quais essa atividade é atomizada, com negociações individualizadas de cada catadora.

Os dias de "entrega" têm estimulado a presença de todas as catadoras e seus familiares, $\mathrm{o}$ que provoca grande movimentação nas ruas desde as 5 horas da manhã. Esses espaços têm servido de distintivo para elas, que explicitam gozar de um reconhecimento do Estado por meio de um programa de política pública chamado localmente Conab. O programa estimulou as participantes a atuar em um grupo constitu- ído exclusivamente pelas catadoras de mangaba, muito embora formalmente elas participem como cooperadas da Ascosul, e não como comunidade agroextrativista (CONAB, [2011]). Isso tudo num contexto em que o referencial para a agregação das pessoas de diferentes mundos sociais era derivado da ação de membros das famílias mais tradicionais por ocasião das festas religiosas e dos festejos que demarcavam os tempos de festa contrapostos aos de trabalho.

Assim sendo, as ações em torno do PAA têm contribuído para provocar uma reinterpretação da vida local e da maneira de se colocar diante do outro, tanto pelas catadoras, como pelos demais atores. Em reação, o processo acaba acirrando a oposição dos proprietários que criticam o PAA por comprar frutas coletadas pelas catadoras em estabelecimentos de terceiros. Eles temem perder os direitos sobre as suas próprias terras, particularmente diante da possibilidade de constituição de uma Resex naquela região. Com efeito, a discussão sobre isso foi retomada como uma das prioridades do governo federal em 2011. Em consequência, os proprietários apertam o cerco, dificultando a continuidade de acordos históricos com as catadoras.

Como analisado, a participação no PAA tem suscitado um novo posicionamento das catadoras de mangaba individualmente e como membros de um grupo. Consequentemente, estabelecem-se novos papéis e hierarquias entre as lideranças, os mediadores e as próprias catadoras. As lideranças das catadoras de mangaba e os mediadores viajam e relacionam-se com o corpo burocrático de outras instituições, divulgando as informações localmente, organizando as "entregas" (anotam, pesam) e interligando diferentes universos. Mesmo as catadoras que localmente partilham uma situação comum, diferenciam-se, havendo particularidades entre as "catadoras da Rua de Baixo" e as "catadoras da Rua de Cima". As primeiras, residentes na parte mais nova do povoado, também apontadas como as mais recentes no povoado por alguns entrevistados, realizam a "entrega" na garagem de 
uma casa em construção, localizada na esquina da Rua das Mangabeiras ${ }^{33}$. As demais, residentes na parte de cima do povoado, são consideradas as mais antigas e "entregam" os frutos na sede da Associação de Moradores do povoado. Distinguem-se também pelos arranjos familiares que instituem para lidar com as frutas nos processos de coleta, pós-coleta e acondicionamento, liderando a divisão do trabalho entre os membros do grupo doméstico. Todos esses arranjos são observados e comentados por todos. Uma vasilha com frutos verdes no momento da "entrega" é motivo de observações sutis, do tipo "brincadeira", para repreender aquela que desrespeitou uma regra importante que é retirar frutos apenas em via de amadurecimento. Também se tecem críticas posteriores às infrações à regra. Desse modo, tentativas de controle social são postas em prática. $\mathrm{O}$ volume de frutos é motivo tanto de dedução da capacidade de trabalho e acesso aos frutos, quanto de indicação do recurso a ser recebido. Consequentemente, a própria aplicação do dinheiro em bens ou serviços é objeto de observações e de comentários entre as catadoras.

No correr da "entrega", são frequentes os relatos dos processos de coleta, enfatizando as dificuldades, paralelamente aos relatos de fatos engraçados e perigosos que tenham ocorrido naqueles processos, principalmente nas áreas que são objeto de disputa entre as catadoras e outros.

Nos dois espaços de "entrega", observa-se que as catadoras criticam quando o transporte das frutas para as instituições não é feito adequadamente - quando são usados sacos de plástico em vez de caixas, o que ocasiona o escurecimento das frutas. Demonstram temer reclamações por parte dos receptores da mangaba mostrando reconhecer o poder dos consumidores num programa dessa natureza.

33. A rua tem esse nome porque até recentemente havia muitas mangabeiras que estão sendo, pouco a pouco, cortadas para dar lugar a casas de alvenaria que substituem as anteriores, de palha. Nos arredores residem as catadoras que são chamadas "catadoras da Rua de Baixo".

\section{Mudanças na autoestima, no consumo e nos sonhos}

A demonstração da satisfação de participar do PAA é frequente entre as catadoras de mangaba e também entre outros grupos de mulheres, como mostram Siliprandi e Cintrão (2011) e Jalil (2010). A inserção em um programa de política pública, com uma remuneração considerada justa, tem contribuído não somente para a valorização e o reconhecimento das mulheres, mas também para a ampliação dos sonhos, como revelado na fala da presidente da Associação das Catadoras de Mangaba de Indiaroba (Ascamai):

"Ah! Pros meus filhos eu desejo que eles estudem, que eu possa ter pra bancar depois uma faculdade, uma coisa boa pra eles, e que eles também vivam como eu estou vivendo, tenham futuramente onde pegar [mangaba], porque eu sei que quem vive aqui, quer queira quer não, mas precisa da mangaba, precisa do mangue também. Porque assim são as coisas que, mesmo que você tenha outro meio de ter uma rendazinha, mas são acréscimos, né? Hoje a minha convivência é através da mangaba, a mangaba e o mangue, mais a mangaba hoje do que o mangue. Porque o mangue a gente não é reconhecido, né, assim, como é que se diz? Cadastrado pelo mangue, é mais pela mangaba, porque eu faço muito hoje com a mangaba, faço bem. O meu ganho maior hoje é da mangaba, vendendo na Conab, aqui mesmo, como você viu, aí a gente tira, chega em casa, é só cuidar, lavar direitinho. No dia da entrega, pega, leva e entrega. Na feira, você ainda ia ficar o dia todinho suando pra mandar duas caixas. E agora não tem nem comparação, né?" (Alícia Salvador, Presidente da Associação das Catadoras de Mangaba de Indiaroba).

As catadoras de mangaba tiveram no PAA a primeira possibilidade de aumento de renda a partir da comercialização do fruto in natura. Novos sentidos são atribuídos à atividade, o que implica reinterpretação da própria condição de catadora de mangaba, que prevê uma relação 
entre a existência do fruto e uma inserção dos filhos no ensino universitário no futuro. Essa reinterpretação confirma a ideia da permanente recriação da condição de catadora de mangaba, negando o congelamento das suas formas de existência.

Mesmo que não tenhamos registrado literalmente esse conteúdo nas entrevistas das demais catadoras, a ideia de reconhecimento, de valorização e de segurança é expressa em suas falas:

"A pessoa tira a mangaba, pesa e tem o dinheiro certo" (E.M.C., catadora de mangaba, 46 anos).

"A vida continua a mesma, o que mudou foi o prestígio, porque todo mundo me conhece como a menina da mangaba, mas eu sou sozinha, aí não cata tanto. Mudou, porque tem a pessoa certa para entregar [a Conab]" (A.C.O.S., catadora de mangaba, 22 anos).

Entretanto, diferente do que diz a presidente da Associação das Catadoras de Mangaba de Indiaroba, é o tempo presente que é indicado nesses depoimentos. É ressaltado o aspecto mais positivo do PAA - a segurança de saber que receberão por todos os frutos coletados, diferente de um passado recente quando, algumas vezes, diante de propostas de compra a preços baixíssimos, elas preferiam jogar fora e até "pisar as mangabas com os pés de tanta raiva e revolta":

"A vantagem é que a gente não perde, não vai para feira e ter que jogar fora quando tem muita mangaba. Já cata e entrega aqui mesmo em Pontal e o tanto que catar, 'entrega'. Já tem valor certo" (S.A.S, catadora de mangaba, 35 anos).

"Antes entregava a atravessador e eles pagavam pouco. Uma caixa era 15 reais. Entrei porque na safra o tanto que tiro entrega, eles pegam tudo que eu cato" (A.P., catadora de mangaba, 34 anos).

"A vantagem é grande, tem muita coisa, ganha mais do que o atravessador paga. No PAA entregamos 'de vez' e madura e para o atravessador não podia 'de vez'. Deu rendimento, cresceu o grupo, me entusiasmei mais" (A.M.S.S., catadora de mangaba, 25 anos).

Porque a pessoa ganha o dinheiro, é uma ajuda a mais. Deixei de entregar a atravessador, porque no projeto entrega mais em quantidade de quilo (A.C.O.S., catadora de mangaba, 22 anos).

A diminuição da vulnerabilidade tem sido muito enfatizada como também a possibilidade de "entregar" a fruta por um preço fixo, o que permite calcular o que será recebido e assumir compromissos financeiros e comprar mais, em contraste com um passado recente de privações, inclusive alimentares. Tudo isso informa sobre um sujeito que nega uma existência no limite da sobrevivência.

Pequenos trechos de conversas ouvidas na pesquisa de campo são reveladores: "tendo muita fruta, recebe bem"; "consigo pagar as minhas contas", "agora lavo meu cabelo com xampu porque antes era com sabão". Frequente também é a alusão à abertura de uma conta no banco, pela primeira vez, por meio da qual recebem os recursos do PAA.

Por tudo isso, a participação no PAA tem influenciado na autoestima, no maior reconhecimento local e no reposicionamento das mulheres catadoras na própria família por aportarem recursos que têm contribuído para o bem-estar de todos. Não estamos deduzindo disso que as necessidades das catadoras e de suas famílias estão satisfeitas, mas é significativo que todas as 36 entrevistadas (100\%) afirmem que as suas vidas melhoraram pelo pagamento de contas atrasadas. A maior parte dessas contas resulta da aquisição de alimentos em comércios locais (83\%), pela aquisição de alimentos - particularmente carne, que substitui os mariscos na alimentação, uma vez que agora as catadoras de mangaba não têm tempo para coletá-los $(66 \%)$-, mas também se devem à aquisição de móveis e à reforma da casa $(55 \%)$.

Não se sugere, com isso, que antigas desigualdades associadas ao gênero foram superadas, mas não há dúvida de que as mulheres catadoras de 
mangaba conquistaram novas posições e maior capacidade de decisão quanto aos gastos, mesmo que tendam a priorizar as necessidades do grupo doméstico, como também observado em outros contextos (GODDARD, 1996):

“Quando viajo para Indiaroba ou Estância, aí compro pras três filhas coisas para elas usarem, como calçados e roupas, porque se der o dinheiro na mão delas, elas gastam tudo em doces" (M.J.C.S., catadora de mangaba, 33 anos).

A satisfação das catadoras e dos seus familiares com o PAA é claramente visível e chega ao ponto de modificar o ordenamento das atividades e os modos de socialização das crianças costumeiramente praticados. A certeza da recompensa tem contribuído para que a coleta da mangaba seja prioritária na safra em detrimento de outras atividades, como a coleta animal no mangue, cujos produtos se destinavam tanto ao consumo quanto à venda.

Os indícios de uma reestruturação do mercado local a partir da afiliação das catadoras ao PAA ainda são controversos como mostram os depoimentos:

"Mudou o preço [da mangaba], porque os atravessadores começaram a pagar mais, uma caixa de 15 passou a ser 35 reais" (A.P., catadora de mangaba, 34 anos).

"Aumentou o preço que os atravessadores pagam, eles pagam 25 reais quando não está na safra. Na safra, é a mesma coisa de sempre ou menos, porque tem muita mangaba. $\mathrm{O}$ dinheiro é mais no PAA. Uma caixa dá mais de 20 quilos e os atravessadores só pagam 20 reais, e no PAA é 1,50 por quilo" (A.M.S.S., catadora de mangaba, 25 anos).

Tais divergências podem decorrer das variações de preços entre os atravessadores, que seriam provocadas pelas modificações associadas ao PAA. Para outras catadoras, entretanto, as variações nos preços resultam da maior ou menor oferta das frutas, independente do PAA:

Não mudou o preço da mangaba, os atravessadores oferecem o mesmo preço [de sempre] pelas caixas (A.C.O.S., catadora de mangaba, 22 anos).

Os atravessadores tão comprando a caixa [de mangaba] pelo mesmo preço, mas é menos que o PAA paga. Quando tá na safra mesmo, os atravessadores querem pagar besteira, 15 a 17 reais pela caixa de 30 quilos (M.J.C.S., catadora de mangaba, 33 anos).

Apesar das diferentes interpretações da influência do PAA nos canais locais de comercialização, há quem "entregue" mangaba tanto ao PAA, quanto ao atravessador. Uma catadora levanta uma importante questão quanto ao futuro: "E se o PAA acabar? Eu num posso pensar só nele, não é? Também não posso deixar os que compravam antes assim na mão" (K.M., catadora de mangaba, 28 anos).

Constata-se que, após o término de um programa de política pública, persiste o desafio de manter a autonomia produtiva dos participantes, garantindo-lhes a geração de renda. Isso é particularmente válido para o PAA, que faz parte de uma política de governo que se pretende transitória - o Programa Fome Zero. No caso em análise, a adoção do PAA como a quase exclusiva alternativa de mercado não tem levado à criação de novas possibilidades, o que agrava a situação daqueles que não têm o acesso garantido aos recursos.

\section{Reflexões finais}

O PAA é o primeiro incentivo à comercialização formal oferecido a um grupo de mulheres catadoras de mangaba no Brasil. Se, por um lado, estabelece uma diferença importante em relação a um passado de inserções descontínuas e incertas nos mercados locais (feiras e atravessadores), por outro, incentiva questionamentos quanto ao futuro.

A originalidade do programa no que diz respeito à recepção e à distribuição de um fruto in natura na mesma região gera um clima de otimismo entre produtores e consumidores e pro- 
move o potencial aquecimento da economia local. Ademais, o PAA tem favorecido a criação de espaços de sociabilidade e de vivência de uma experiência que valorizou o extrativismo, uma atividade altamente tradicional, mas seu futuro é questionado, tanto por intelectuais, quanto por outros atores que defendem um uso diferenciado dos recursos naturais.

Um requisito essencial para a execução do programa é a ação dos mediadores e das lideranças, que eles lidam com a burocracia e facilitam arranjos locais, viabilizando o programa. Por isso, Grisa et al. (2009) afirmam que, em cada contexto, o PAA "assume arranjos institucionais peculiares". No caso do Povoado Pontal, observou-se a mobilização de uma cooperativa, de uma prestadora de serviços e de uma associação local de moradores.

Apesar do forte investimento no PAA e do conhecimento da estratégia de execução local, as catadoras desconhecem as regras de funcionamento estrutural e os objetivos de longo prazo do programa. Por conseguinte, mantêm forte dependência dos mediadores.

Após cinco anos de participação no PAA, os diferentes atores entrevistados estão unânimes quanto às virtudes do programa no Pontal. Mais especificamente, observa-se melhoria na autoestima das catadoras expressa pela demonstração do orgulho decorrente do reconhecimento formal das suas existências e da atividade, pelo sentimento de valorização do próprio trabalho, dada a certeza da venda da fruta a um preço que consideram justo, e pela ampliação da capacidade de consumo, inclusive de alimentos para a família e de itens pessoais.

Porém, se todas as vantagens do programa são vivenciadas localmente, as dificuldades para ter acesso aos frutos também o são, por causa da crescente privatização das áreas com mangabeiras. Assim, acirram-se os atritos entre as catadoras e os proprietários de terra que veem o PAA como uma iniciativa de reforço da existência das catadoras como sujeito coletivo, com perspectiva de novas conquistas, que podem, inclusive, ocasionar a desapropriação das suas terras.
Com a diminuição das áreas para a coleta, ensaiam-se também entre as catadoras disputas pelos frutos. Várias catadoras fizeram referência a essas disputas, mas nenhum confronto aberto foi identificado, embora comentários sobre as discordâncias circulem em diferentes grupos, cumprindo um papel de informar as disputas sem opor os discordantes. Mesmo assim, as catadoras chamam a atenção para os problemas que extrapolam um programa dessa natureza, aplicado a uma comunidade extrativista sem acesso garantido aos recursos.

Diferente dos agricultores com terra que podem planejar e diversificar a sua produção (guardados os riscos inerentes à atividade agrícola), as catadoras de mangaba não têm garantia de acesso aos recursos. Consequentemente, têm dificuldade para prever quanto exatamente podem coletar, além de dependerem de um fruto que é sazonal e disputado por muitas pessoas. Mesmo assim, elas estabeleceram diferentes arranjos para atender às exigências legais do PAA juntando temporariamente os frutos para a comercialização - como fez aquela catadora possuidora da DAP - até chegarem à regularização da situação. Desse modo, o PAA atendeu a um maior número de mulheres de uma mesma família, reforçando laços familiares e valores como a confiança. Como constatado, os procedimentos previstos no PAA têm sido readaptados localmente para facilitar a inclusão de um número maior de catadoras. Sugere-se que os legisladores do PAA façam dessa situação um objeto de reflexão para redimensionarem o programa.

A maioria das catadoras tem investido quase exclusivamente no PAA, considerado por elas como a alternativa mais compensadora e com garantia de pagamento. Nesse processo, as relações com agentes do mercado local foram quase rompidas, do mesmo modo que as vendas nas feiras foram suprimidas. Seria interessante verificar a repercussão dessas ausências nos mercados locais, a longo prazo.

É evidente a forte influência do PAA no modo de vida das catadoras e de seus familiares. Constata-se que houve um reordenamento das 
atividades (mangaba em detrimento do manguezal, por exemplo), a entrega dos frutos no mesmo espaço e tempo, uma reorganização do trabalho no campo para a coleta e na casa para a pós-coleta, com o envolvimento do maior número de membros da família e a busca de áreas mais distantes e com maior possibilidade de encontrar frutos - pelo menos por parte de algumas catadoras. Ademais, começam a existir acordos monetários entre catadoras e proprietários para garantir acesso ao fruto. Mas também há catadoras que dependem menos da venda de mão de obra.

É consenso que os recursos aportados pelo PAA têm contribuído para a melhoria da qualidade de vida das catadoras a curto prazo. Mesmo assim, existe a compreensão de que o PAA não garante a persistência das catadoras na atividade, muito embora tenha o potencial de fortalecer sua visibilidade social e criar novas alianças para lutar por ela. Essa etapa da experiência com o PAA, portanto, ilustra a chamada "satisfação de necessidades práticas", sem o cumprimento das necessidades políticas, no sentido de que as participantes percebem as vantagens imediatas, mas ainda não concebem o programa como uma alavanca para a transformação dos diferenciais de poder que perpetuam as condições estruturantes da pobreza que gera a fome, que o PAA visa combater.

Por fim, conclui-se que o atendimento às necessidades políticas dá-se num processo de disputa para garantir o acesso aos recursos por meio da criação de uma reserva extrativista na região sul de Sergipe, onde se localiza o Pontal. Estamos convictos de que a participação das catadoras no PAA reforça a sua visibilidade e influencia significativamente num processo que parece garantir às extrativistas o seu futuro como catadoras.

\section{Referências bibliográficas}

ABRAMOVAY, R. Paradigmas do capitalismo agrário em questão. São Paulo: Editora Hucitec, 1992. 275p.

AGUIAR,V. V. P. Margaridas em marcha: mulheres do campo e da floresta se construindo como sujeito político. 2011. 55 f. Projeto de qualificação (Doutorado em Ciências Sociais) - Instituto de Filosofia e Ciências Humanas, Universidade Estadual de Campinas, Campinas, 2011.

BOURDIEU, P. Algerische Skizzen. Hrsg. Tassadit Yacine. Berlin: Suhrkamp, 2010. 523p. Original: 2008.

BRODBECK, K. H. Ökonomie der Armut. In: SEDMAK, C. (Org.). Option für die Armen: Die Entmarginalisierung des Armutsbegriffes in den Wissenschaften. Freiburg: Herder Verlag, 2005. p.59-80.

CASTRO, E. Território, biodiversidade e saberes de populações tradicionais. In: CASTRO, E. e PINTON, F. (Org.). Faces do Trópico Úmido: conceitos e questões sobre desenvolvimento e meio ambiente. Belém: Cejup, 1997. p.263-283.

CEPAL. Indicadores de pobreza y pobreza extrema utilizadas para el monitoreo de los ODM en América Latina. Santiago de Chile: Comisión Economica para a América Latina e el Caribe, [2011]. 4p. Disponível em: <http://www.eclac.cl/cgi-bin/getprod.asp?xml=/ MDG/noticias/paginas/1/40211/P40211.xml\&xsl=/ MDG/tpl/p18f-st.xsl\&base=/MDG/tpl/top-bottom.xs $>$. Acesso em: 12 fev. 2012.

CHAYANOV, A. V. La organización de la unidad económica campesina. Buenos Aires: Nueva Vision, 1974. 339p. Primeira publicação em alemão 1923.

CHMIELEWSKA, D., SOUZA, D. e LOURETE, A. A. O Programa de Aquisição de Alimentos da Agricultura Familiar (PAA) e as Práticas dos Agricultores Participantes Orientadas ao Mercado: estudo de caso no Estado de Sergipe. Brasília: IPEA, 2010. Texto para Discussão n. 1510.

CONAB. PAA: Resultados da Conab em 2010. Brasília: Companhia Nacional de Abastecimento, [2011]. 16p. Disponível em: < http:/www.conab.gov.br/OlalaCMS/ uploads/arquivos/11_04_05_16_19_56_sumario_ executivo_2010.pdf $>$. Acesso em: $1 \overline{9}$ fev. $20 \overline{1} 2$.

CONAB. Programa de Aquisição de Alimentos: renda para quem produz e comida na mesa de quem precisa. Brasília: Companhia Nacional de Abastecimento, [2007]. 23p. Disponível em: <http://www.mda.gov. br/portal/saf/arquivos/view/paa/Cartilha_PAA.pdf $>$. Acesso em: 13 fev. 2012.

COSTA, F. A. Formação agropecuária da Amazônia: os desafios do desenvolvimento sustentável. Belém: NAEA/UFPA, 2000. 355p.

COSTA, S. Vom Nordatlantik zum Black Atlantic: postkoloniale Konfigurationen und Paradoxien transnationaler Politik. Bielefeld: Transcript, 2007. 292 p. 
DELGADO, G., CONCEIÇÃO, J. C. P. R. da e OLIVEIRA, J. J. Avaliação do Programa de Aquisição de Alimentos da Agricultura Familiar (PAA). Brasília: IPEA, 2005. Texto para Discussão no 1145. Brasília: IPEA, 2005.

DORETTO, M. e MICHELLON, E. Avaliação dos impactos econômicos, socias e culturais do Programa de Aquisição de Alimentos no Paraná. Sociedade $e$ Desenvolvimento Rural, Brasília, v 1, n. 1, 2007. 28p. Disponível em: <http://www.iapar.pr.gov.br/arquivos/ File/zip_pdf/aval_impact_econo.pdf $>$. Acesso em: 3 abr. 2013.

ELLIS, F. Peasant Economics. Farm households and agrarian development. 2. ed. Cambridge: Cambridge University Press, 1993. 309p. Original: 1988.

FERNANDES, B. M. Agricultura camponesa e/ ou agricultura familiar. In: Encontro Nacional de Geógrafos, 8., 2002, João Pessoa. Anais... João Pessoa, 2002. CD-ROM.

FILLIEULE, O. Conscience politique, persuasion et mobilisation des egagements. L'exemple du syndicat des chômeurs 1983-1989. In: FILLIEULE, O. (dir.). Sociologie de la protestation: les formes de l'action collective dans la France contemporaine. Paris: L'Harmattan, 1993. p. 123-155.

FRASER, N. Soziale Gerechtigkeit im Zeitalter der Identitätspolitik. In: FRASER, N.; HONNETH, A. Umverteilung oder Anerkennung? Eine politischphilosophische Kontroverse. Frankfurt a.M.: Suhrkamp Verlag, 2003. p. 13-128.

GODDARD, V. A. Gender, Family and Work in Naples. Oxford: Berg Publishers. 1996, 264p. Mediterranea Series.

GRISA, C., SCHMITT, C. J., MATTEI, L. F., MALUF, R. S. e LEITE, S. P. O Programa de Aquisição de Alimentos (PAA) em Perspectiva: Apontamentos e Questões para o Debate. Rio de Janeiro: UFFRJ/CPDA, 2009. 24p. Disponível em: < http://oppa.net.br/acervo/publicacoes/Pesquisa_ AABR-OPPA_Texto_PAA_versao_livro.pdf $>$. Acesso em: 13 fev. 2012.

HOMMA, A. K. O. Extrativismo vegetal na Amazônia: limites e oportunidades. Brasília: Embrapa-SPI, 1993. 202p.

HOMMA, A. K. O. Evolução histórica dos macrossistemas de produção na Amazônia. In: Encontro da Sociedade Brasileira de Sistemas de Produção, 4., 2001, Belém. Anais... Belém: SBSP; UFPA, 2001. CD-ROM.

HONNETH, A. Umverteilung als Anerkennung. Eine Erwiderung auf Nancy Fraser. In: FRASER, N. e HONNETH, A. Umverteilung oder Anerkennung? Eine politisch-philosophische Kontroverse. Frankfurt a.M.: Suhrkamp Verlag, 2003. p.129-224.

JALIL, L. A experiência da prática de monitoramento do Programa de Aquisição de Alimentos - PAA como política vivida: um estudo de caso em Mirandiba/PE e Esperantina/PI. In: Encontro da Rede de Estudos Rurais, 4., 2010, Curitiba. Anais... Curitiba: UFPR, 2010. 10p. Disponível em: <http://www.redesrurais. org.br/sites/default/files/A\%20experiencia $\% 20$ do $\% 20$ monitoramento $\% 20$ do $\% 20$ programa $\% 20 \mathrm{de} \% 20$ aquisicao\%20de\%20a.pdf >. Acesso em: 27 mar. 2012.

KAGEYAMA, A. e HOFFMANN, R. Pobreza no Brasil: uma perspectiva multidimensional. Economia e Sociedade, Campinas, v. 15, n. 1 (26), p. 79-112, jan./jun. 2006.

LAMARCHE, H. (Coord.). A agricultura familiar: comparação internacional. Vol. 1. Uma realidade multiforme. Trad. A. M. N. Tijiwa. Campinas: Editora da Unicamp, 1993. 336p.

MARTINS, J. de S. O sujeito oculto: ordem e transgressão na reforma agrária. Porto Alegre: Editora da UFRGS, 2003. 238p.

MINAYO, M. C. de S. Pesquisa social: teoria, método e criatividade. 6. ed. Petrópolis: Vozes, 1994.

MOREIRA, H. C. L., SCHERER, E. F. e SOARES, S. M. O seguro defeso do pescador artesanal: políticas públicas e o ritmo das águas na Amazônia. In: Congreso Latinoamericano de SociologÍa Rural da Associação Latino-Americana de Sociologia Rural (ALASRU), 8., 2010, Ipojuca-PE. Anais... Ipojuca-PE: Alasru, 2010. 11 p.

MOTA, D. M. da, SILVA JÚNIOR, J. F. da e GOMES, J. B. V. Lógicas de reprodução social de uma população tradicional de catadores de mangaba no litoral sul sergipano. In: Simpósio Brasileiro sobre a Cultura da Mangaba, 2003, Aracaju. Anais... Aracaju: Embrapa Tabuleiros Costeiros, 2003. CD-ROM

MOTA, D.M. da, SCHMITZ, H., SILVA JUNIOR, J.F. da, RODRIGUES, R.F.A. e ALVES, J.N.F. O extrativismo de mangaba é "trabalho de mulher"? Duas situações empíricas no Nordeste e Norte do Brasil. Novos Cadernos NAEA, v. 11, n. 2, p. 155-168, dez. 2008.

MÜLLER, A. L., FIALHO, M. A. V. e SCHNEIDER, S. A inovação institucional e a atuação dos atores locais na implementação do Programa de Aquisição de Alimentos no Rio Grande do Sul. Sociedade $e$ Desenvolvimento Rural, Brasília, v 1, n. 1, 2007. 36p. Disponível em: < http://www.inagrodf.com.br/revista/ index.php/SDR >. Acesso em: 13 fev. 2012.

NAKAZONO, E. M. O empreendimento local do artesanato em fibras vegetais na Amazônia Brasileira. 2007. 309 f. 
Tese (Doutorado em Desenvolvimento Sustentável no Trópico Úmido) - Núcleo de Altos Estudos Amazônicos (NAEA), Universidade Federal do Pará, Belém, 2007.

PORRO, N., VEIGA, I. e MOTA, D. Traditional communities in the Brazilian Amazon and the emergence of new political identities: the struggle of the quebradeiras de coco babaçu - babassu breaker women. Journal of Cultural Geography, v. 28, n. 1, p. 123-146, 2011.

ROCHA, M.M.L. Relatório de pesquisa sobre os conflitos no Povoado Pontal. Aracaju, 2011.

SCHMITZ, H. Campesinato: ensaio sobre a utilidade de um conceito na atualidade brasileira. In: Encontro da Associação Nacional de Pós-graduação e Pesquisa em Ciências Sociais (Anpocs), 32., 2008, Caxambu. Disponível em: $\quad$ http://200.152.208.135/anpocs/trab/pub/lista grupos_aprovados.tpl.ph >. Acesso em: 8 nov. 2008.

SCHMITZ, H., MOTA, D. M. da e SILVA JÚNIOR, J. F. da. Gestão coletiva de bens comuns no extrativismo da mangaba no Nordeste do Brasil. Ambiente \& Sociedade, Campinas, v. 12, n. 2, p. 273-293, jul./dez. 2009.

SCHMITZ, H., MOTA, D. M. da e SILVA JÚNIOR, J. F. da. Mangabeiras cercadas e soltas: formas de acesso, coleta e gestão das plantas. In: MOTA, D. M. da, SILVA JÚNIOR, J. F. da, SCHMITZ, H. e RODRIGUES, R. F. de A. (Eds.). A mangabeira, as catadoras, o extrativismo. Belém: Embrapa, 2011. p. 171-202.
SHANLEY, P., LUZ, L. e SWINGLAND, I. R. The faint promisse of a distant market: a survey of Belem's trade in non-timber forest products. Biodiversity and Conservation, v. 11, p. 661-686, abr. 2002.

SILIPRANDI, E. e CINTRÃO, R. As mulheres agricultoras e sua participação no Programa de Aquisição de Alimentos (PAA). 2011. 27p. Disponível em: $<$ http://www.iica.int/Esp/regiones/sur/brasil/Lists/ DocumentosTecnicosAbertos/Attachments/310NEAD. pdf > . Acesso em: 28 nov. 2011.

SILVA JÚNIOR, J. F. da, MOTA, D. M. da e GOMES, J. B. V. Representações de uma população tradicional de catadores acerca do extrativismo da mangaba no litoral sul de Sergipe. In: Simpósio Brasileiro sobre a Cultura da Mangaba, 2003, Aracaju. Anais... Aracaju: Embrapa Tabuleiros Costeiros, 2003. CD-ROM

TARROW, S. O poder em movimento: movimentos sociais e confronto político. Petrópolis: Vozes, 2009. 319 p. Original 1994.

WIGGERS, R. Mediadores sociais e políticos: Estado, Lideranças e Comunidades na Amazônia. In: Encontro da Rede de Estudos Rurais, 4, 2010, Curitiba. Encontro da Rede de Estudos Rurais, 4. Anais... Mundo rural, políticas públicas e atores em reconhecimento político. Curitiba: Programa de Pós-Graduação em Sociologia, UFPR, 2010. CD-ROM. 
